\title{
THE TEACHER: FROM A RESPONSIBLE STUDENT'S POINT-OF-VIEW
}

\author{
Marijke Hezemans and Magda Ritzen \\ Hogeschool van Utrecht,University for Professional Development and Applied Science: \\ CETIS, Expert Centre for Educational Innovation and Training
}

\begin{abstract}
Dutch universities of professional education are working with institutions in the field to develop programmes that are intended students to develop into starting professionals. The implementation of these new programmes means adopting a new methodology and this assumes that the teacher learns. This paper will show by means of a case description how a teacher, supported by ICT, can realise a personal learning process in such as way as to effectively guide and supervise an analogous learning process for the student. In this case the teacher and the student are central. The professional field provides the tools for practising this competence management.
\end{abstract}

Key words: learning models, cognition, collaborative learning

\section{INTRODUCTION}

Dutch universities of professional education are working in co-operation with institutions in the field to develop and implement programmes that are intended to give students optimum preparation for the reality and dynamics of professional practice. These new programmes aim to provide learning environments that enable students to develop into starting professionals: they develop their competence and professional expertise in learning environments of varying complexity.

This paper will show, by means of a case description, how a teacher supported by ICT can realise a personal learning process in such as way as to effectively guide and supervise an analogous learning process for the student. In this case the teacher and the student are central. The professional 
field provides the tools for practising this competence management. The case description is taken from the project 'Competence development \& portfolio': a project which is carried out in the part-time economics programmes at the Utrecht University of Professional Education (Hogeschool van Utrecht).

The project aims to maximise the part-time students' competence development (learning) with the help of a digital learning environment (efolio environment) developed by teachers who are coached by two educational staff members attached to the project. In this learning environment part-time students learn among other things to reflect on their work experience by means of a personal development plan and the competence profile of the programme. As well as self-reflection, which on the student's initiative is coached by the teacher, reflection also takes place in peer groups.

During the project a digital portfolio (e-folio) is developed to support and make visible competence development. The e-folio is a protected area in the e-folio environment that is only accessible to the owner of the e-folio. The owner can make (parts of) the e-folio accessible to others. The e-folio has a dual function within the learning environment:

1. As an instrument for supporting and making explicit development and reflection (Kösters \& Ritzen, 2001); and

2. As a showcase on the basis of which assessment can take place (Schulman, 1998).

The e-folio supports the students in carrying out their personal development plans, in which learning outcomes are defined in relation to the competence profile of the programme. Accompanying assignments, and a coaching and assessment protocol are also developed, so that teaching and assessment are also related to the competence profile of the programme.

\section{THE E-FOLIO TEACHER: COMPETENCE DEVELOPMENT}

The 'Learning environments and responsibility' model (Hezemans \& Ritzen, 2002) was created to support the development and realisation of learning environments as mentioned above. This model sets out the specific contribution, defined in terms of responsibilities, of each of the three parties (students, teachers and the professional field) who are involved in competence-based learning environments which enable students to develop into starting professionals. The model aims to give an overview of the most important principles and moments of choice for the development of learning environments. The model emphasizes that within every type of learning 
environment the teacher is responsible for defining assignments for the students. To create the optimum learning environment all parties involved need to share responsibility. The 'Learning environments and responsibility' model implies that the student, the teacher and the professional (representative from the field) learn and develop. Hence the introduction of new competence-based programmes means adopting a new methodology and this assumes that the teacher also develops competencies and professional expertise in relation to the programme (Witteman, 2001).

\subsection{Learning programme for the e-folio teacher}

Analogous to the part-time students' learning process a programme was set up within the project in co-operation with the Virtual Learning Centre (VLC) of the Utrecht University of Professional Education to support the teachers' competence development in the e-folio environment. The teachers can only take part in the 'e-folio teacher' learning programme when they are actually teaching students who are working with an e-folio. The aim of the course is two-fold:

1. To train competent e-folio teachers, both in relation to guiding the students' development as well as ICT-skills; and

2. To act as an example to students and colleagues.

A competence profile for an 'e-folio teacher' was developed, in which competencies relevant for the effective teaching of students working with an e-folio are defined (Hezemans \& Kinkhorst, 2002). This teaching method is based on the principle of 'learning to learn'. The following competencies were included in the profile:

Table 1. Competencies of an 'e-folio teacher

\begin{tabular}{ll}
\hline Competency & Description \\
\hline Coaching & The ability to stimulate, direct and accelerate students' development. \\
$\begin{array}{l}\text { Problem } \\
\text { analysis and } \\
\text { judgement }\end{array}$ & $\begin{array}{l}\text { The ability to analyse problem situations and make an adequate } \\
\text { estimate of their importance for the student's development. }\end{array}$ \\
Integrity & $\begin{array}{l}\text { The ability to be open and honest, and to act according to the values, } \\
\text { norms and responsibilities belonging to the role of teacher. }\end{array}$ \\
Ability to learn & $\begin{array}{l}\text { The ability to actively acquire knowledge, skills and attitude, to } \\
\text { continue to develop one's own practice and to continue to develop } \\
\text { products. }\end{array}$
\end{tabular}

Starting from their personal learning needs (personal competence profile), the e-folio teachers each made a personal development plan. The 
development plan shows the way in which the above competencies will be developed (learning activities) and which forms of support (e.g. training or peer assisted learning) are needed. The teachers collect their evidence in their digital portfolio (e-folio) by means of which they can demonstrate that they have completed learning activities and thus have developed the above competencies.

\subsection{Assessment}

The course is rounded off with an e-folio assessment (Hofman \& Kinkhorst, 2002). In the e-folio assessment two assessors independently assess the evidence presented in relation to the competence profile of an 'efolio teacher'. When teachers judge that they are ready for the e-folio assessment, they apply for the assessment by submitting the e-folio to the assessors. The first and second assessor judge the e-folio independently of each other according to the following criteria:

1. The competencies of an e-folio teacher as operationalised in the competence profile of an 'e-folio teacher':

Does the teacher possess a behavioural repertoire which sufficiently covers the competence profile?

2. Ability to learn: Are teachers able to learn through working, to recognise and use their qualities, and to recognise and compensate for their limitations?

On the basis of the following elements: relevance (the material is relevant to the competence involved); concreteness (the evidence is sufficiently concrete and specific); depth (of reflection); and coherence (links within evidence are made explicit). The assessment is discussed with the teacher during an e-folio assessment interview.

\section{E-FOLIO TEACHERS LEARNING TOGETHER}

\subsection{Community of e-folio teachers}

The e-folio teachers expressed the need to exchange ideas and share experience in relation to the supervision of students and their own learning. The teachers are aware of the opportunities offered by educational innovation for themselves and their students, and are motivated to learn. To support this learning process a digital environment was created in consultation with the teachers and agreements were also made about discussions in person. 
In fact this has led to the creation of a 'Community of Practice'. The most important characteristics of a Community of Practice are (McDermott, 2001, Wenger \& Snyder, 2000):

1. group size of $3-500$;

2. oriented towards sharing information and experience, and learning together;

3. focussed on a specific domain;

4. based on problem or questions;

5. within or between organisations;

6. not directed towards primary process.

These characteristics apply to the 'community of e-folio teachers' described above. There is a group of people who are working together to exchange and develop knowledge; the community exists thanks to the participants; there is role differentiation; and the community members decide how long and about what they will continue to interact with each other (McDermott, 1999, Römgens, 2001).

The community remains in existence as long as it fulfils a need of its members. The functioning of the community is fed by the experience (practice) which the teachers gain through coaching students in practice. The community aims to learn from this and to arrive at new forms of 'practice': the community is therefore not directly concerned with the primary process.

Communities of Practice demonstrate similarities with peer-assisted learning groups. The difference, however, is that in a Community of Practice members are aiming towards a common product, while members of a peerassisted learning group are mainly learning as individuals (Simons, 2001).

\subsection{Working methods in the community of e-folio teachers}

The teachers come together regularly and are supported in this by two educational staff members from the 'Competence development \& portfolio' project. The staff members (or moderator and facilitator) have expertise in the area and ensure that there is a room for discussion, an agenda (based among other things on the members' contributions), a digital environment and a focus to the discussions. There is no further differentiation of roles.

The community is still closed: only e-folio teachers have access. The reason for this is the vulnerability of working on innovation; the security of learning and working in a trusted group is guaranteed. However for effective knowledge development it is necessary to 'open the shutters', to let the outside world in and to learn from this (van Weert, 2002). Therefore the idea is to eventually open up the community, so that others who are interested can also make a contribution. The community is then made up of experts who 
are involved on the basis of their expertise in various projects and who need each other to really progress with their knowledge development. It is important that the organisation shows that they set store by these developments, by for example showing concern for the members of the community by means of coaching and making time available. Above all a recommendation is given which is true for all communities: 'Be patient'; getting a knowledge development process off the ground in a Community of Practice takes time (McDermott, 1999).

The alternation of physical and virtual is important: in the meetings teachers show each other their approach and discuss problems. Subjects for discussion are for example:

- a teacher thinks it is necessary to direct the students' development according to a pre-arranged time schedule under the motto 'deadlines motivate students';

- another teacher tries to motivate students by getting them to act as sparring partners for each other;

- yet another teacher supervises students digitally and the students hardly have any (physical) contact with each other either.

The question in relation to each of the items above is: What consequences does this have for our teaching practice and do we find this desirable? The experience of working with various methods are exchanged and experiments are carried out on the basis of this. In this way a shared vision is established of what is essential in regard to teaching students and how this relates to one's own learning activities.

The concrete knowledge product which is aimed for consists of guidelines on the basis of which the teacher can decide on and carry out the practice of e-folio teaching. Models of good practice illustrate this. The digital environment is intended for noting appointments and evaluation questions for students to exchange with each other, carrying out short discussions (more extensive discussions take place physically), recording proposals in regard to a teaching methodology and giving examples of good practice. Meetings are also prepared through the digital environment.

\section{CONCLUSION: THE TEACHER, A PROFESSIONAL ROLE MODEL}

In the learning environment described above teachers are actively working to develop competencies and professional expertise; they are learning on-the-job. Working as a professional is in fact characterised by three phases (Simons, 2001): 
1. relate: working with knowledge, learning from working on and making explicit the implicit results of learning;

2. create: extending knowledge by, for example, carrying out research, explicit learning;

3. donate: putting into practice, presenting, promoting one's own knowledge. This also includes the development of the profession. The table below shows how the e-folio teachers realize the work phases defined above.

Table 2. The work phases of a learning e-folio teacher

\begin{tabular}{|c|c|}
\hline $\begin{array}{l}\text { Work phase } \\
\text { of } \\
\text { professional }\end{array}$ & Concretisation in e-folio teacher's learning \\
\hline $\begin{array}{l}\text { Relate } \\
\text { learning from } \\
\text { working }\end{array}$ & $\begin{array}{l}\text { Students' and teachers' learning runs parallel; teachers can only take part } \\
\text { in the 'e-folio teacher' learning programme when they are actually } \\
\text { teaching students who are working with an e-folio. The teacher is asked } \\
\text { to carry out self-assessments and to reflect on these by means of } \\
\text { reflection assignments. } \\
\text { The teacher e-folio functions as a support in making the results of } \\
\text { learning explicit or visible. The e-folio environment includes for } \\
\text { example self-assessment instruments. }\end{array}$ \\
\hline $\begin{array}{l}\text { Create } \\
\text { explicit } \\
\text { learning }\end{array}$ & $\begin{array}{l}\text { As part of the learning programme the teacher is assigned to formulate } \\
\text { learning outcomes in relation to the competence profile of an 'e-folio } \\
\text { teacher'. These outcomes, including learning activities and desired } \\
\text { support, are recorded in a personal development plan. }\end{array}$ \\
\hline $\begin{array}{l}\text { Donate } \\
\text { developing } \\
\text { the profession }\end{array}$ & $\begin{array}{l}\text { During the programme (and possibly after) the teacher is stimulated to } \\
\text { participate actively in the community of e-folio teachers. The aim of } \\
\text { this community is to develop instruments and aids (guidelines) which } \\
\text { will optimise the teaching practice of an e-folio teacher. }\end{array}$ \\
\hline
\end{tabular}

The preceding has shown how teachers as professionals can give form to their own learning process supported by ICT: they create a portfolio, make a personal development plan and participate in a Community of Practice. In the process of teaching, students use the same tools; they too after all are being trained as starting professionals. Through guiding students by means of the same sort of learning assignments as they themselves are carrying out, teachers can act as role models; they show students how they themselves learn as professionals. 


\section{REFERENCES}

Bruining, T., \& Haffmans, J. (2001). Werken aan communities of learning en communities of practice. Verbeteren van leren werken. Interview met R.J. Simons. Opleiding \& Ontwikkeling, 11, 7-10.

Hezemans, M., \& Kinkhorst, G. (2002). Competentieprofiel e-folio begeleider. Utrecht: Hogeschool van Utrecht/Virtueel Opleidingscentrum.

Hezemans, M., \& Ritzen, M. (2002). Learning environments and responsibility. In: D. Passey \& M. Kendall (Eds.), TelE-LEARNING: The Challenge for the Third Millennium. Massachusetts: Kluwer Academic Publishers.

Hofman, K. \& Kinkhorst, G. (2002). Handleiding Portfolio en portfolio-assessment. Utrecht: Hogeschool van Utrecht/Virtueel Opleidingscentrum.

Kösters, J. \& Ritzen, M. (2001). Combining Different Aims in a Portfolio System: a Webbased Portfolio and the Various Ways in which it can serve the Student. Retrieved January 16, 2003, from http://www.cetis.hvu.nl

McDermott, R. (1999). Learning across teams, how to build communities of practice in team organizations. Retrieved January 14, 2003, from: http://www.km-review.com

McDermott, R. (2001). Knowing in Community: 10 Critical success Factors in Building communities of Practice. Retrieved January 14 2003, from $\mathrm{http}: / / \mathrm{www} . c 0-1-1 . c o m /$ knowledge-garden/cop/

Römgens, B. (2001). Inleidende visie Community of Practice. Retrieved January 14, 2003, from http://www.24x7edu.net

Schulman, L. (1998). Teacher portfolios: a theoretical activity. In N. Lyons (Ed.), With portfolio in hand validating the new teacher professionalism. New York: Teachers College Press.

Simons, P .R. J., \& Ruijters, M. (2001). Learning professionals: towards an integrated model. Paper presented at the conference of the European Association for Research on Learning and Instruction, Fribourg, Switzerland.

Weert, van T. J. (2003). New Education: de achterkant van het Digitale Wonderland. Utrecht: Hogeschool van Utrecht.

Wenger, E. C. \& Snyder, W. (2000). Communities of Practice: the Organizational Frontier. Harvard Business Review, January-February, 139-145.

Wenger, E. C. (2001). Supporting communities of practice, a survey of community-oriented technologies, version 1.3. Retrieved January 15, 2003, from http://www.ewenger.com/tech

Witteman, H. (2001). Oude didactiek past niet in nieuwe onderwijsvisies. Thema, Tijdschrift voor Hoger Onderwijs en Management, 1, 17-25.

\section{BIOGRAPHY}

Marijke Hezemans, having gained a teaching diploma in Mathematics and Chemistry as well as a degree in Education, now works as an educational advisor and developer. She supervises both the content of innovation processes: the development of competence-based curriculum elements as well as their organisation: the implementation of competence-based programmes. Magda Ritzen is an educational psychologist and has been working for a number of years on educational innovation and the role played in this by ICT. She works as an educational advisor and project leader on redesigning the curriculum. She is involved in projects in the areas of learning in a real-life setting and portfolio as well as communities of practice. 